\title{
EFFICACY OF LISTENING TO MURATTAL IN REDUCING THE PAIN EXPERIENCED BY ICU PATIENTS
}

\section{Iwan Purnawan*1, Arif Imam Hidayat, Eman Sutrisna², Galih Noor Alivian'1, Ikit Netra Wirakhmi ${ }^{3}$}

1. Department of Nursing, Faculty of Health Sciences, Jenderal Soedirman University, Indonesia

2. Medical Faculty of Jenderal Soedirman University, Indonesia

3. Department of Nursing, Faculty of Health Sciences, Harapan Bangsa University, Indonesia

\section{Article Information}

Received: 8 October 2020

Revised: 1 July 2021

Accepted: 25 November 2021

\section{*Corresponding Author}

Iwan Purnawan

iwan.purnawan@unsoed.ac.id

\section{DOI}

10.20884/1.jks.2021.16.3.1567

\begin{abstract}
Pain is one of the main problems experienced by intensive care unit (ICU) patients. Inadequate treatment can cause adverse effects such as unstable hemodynamics or stress and hinder the healing process. Non-pharmacological intervention is suggested to help ICU patients with pain management. This study aims to identify the effect of listening to murattal on pain among ICU patients. This is a quasiexperimental study with a Pretest -Posttest Control Group Design. The simple random sampling technique was used to select 40 respondents who were then divided into two groups. The Critical Pain Observation Tool (CPOT) was used to measure pain. Statistical analysis was conducted by the paired t-test, Wilcoxon-test, and the Mann Whitney test. Significant decreases in pain scores were observed in treatment groups of 4.5 to $4.0(p=0.013)$. In the control group, there was a significant decrease in pain scores from 4.8 to $4.3(p=0.001)$. There was no significant difference between the median decrease in pain in the intervention group $(0.001(-1-2.0))$ and in the control group $(0.001(0.001-1.0))$ with the $p$ value of 0.242 Conclusion: Listening to murattal does not have a significant effect on the pain experienced by ICU patients.
\end{abstract}

Keywords: Critical patient; ICU; murattal; pain

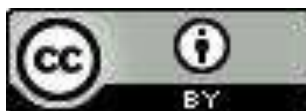

ISSN : 1907-6637

e-ISSN : 2579-9320

\section{INTRODUCTION}

The Intensive Care Unit (ICU) is a medical care facility intended to treat patients with severe and life-threatening conditions. The treatments provided in the ICU generally focuse on physical aspects and usually ignore the patients' psychological and spiritual issues. This is contrary to the ideal conditions where these three factors have an equal and reciprocal effect on one another. Failure to meet one aspect will affect other aspects, which means that the treatment given may not be optimal (Urden et al., 2014).

Disrupting the psychological and spiritual aspects of ICU patients leads to a vulnerable condition of stress. This can worsen the patient's perception of pain (Urden et al., 2014). Injuries, pathological processes, and various surgical procedures are the causes of pain experienced by ICU patients (Urden et al., 2014; Alderson \& Mckechnie, 2013).
Pain is a problem that needs to be dealt with properly. Failure to manage pain in ICU patients may trigger the release of stress hormones such as catecholamines. This hormone will trigger anterior vasoconstriction, thereby inhibiting tissue perfusion, lowering tissue partial oxygen pressure, and increasing body hypermetabolism. This causes additional effects, such as hyperglycemia, lipolysis, and muscle damage. Pain also contributes to delays in the healing process, increases complications, and prolongs the length of stay (LOS) in hospital (Urden et al., 2014).

Pain management for ICU patients is sub-optimal. Many ICU patients still experience pain and discomfort. This may be because the treatments provided to ICU patients did not pay attention to psychological and spiritual aspects. Pain is not only related to physical aspects, but also to motivation and other emotional components. Therefore, complementary 
therapies are recommended to meet the psychological and spiritual needs of ICU patients to produce a synergistic effect that increases the efficacy of standard therapy (Berntzen et al., 2018); Klein et al., 2010).

Listening to murattal as a form of religious activity is considered a form of therapy. This is based on the Quran, as Surah Al Isra verse 82 stated that "And We sent down from the Quran something that is an antidote and a mercy to those who believe ...". Murattal is a technique for reading the Quran that is done in a slow tempo and a steady rhythm. This technique is generally used for religious activities requiring serenity, such as prayer (Fajar, 2016).

The therapeutic effect of listening to murattal comes from the balance of rhythm, flow of words, and the richness of meaning of the Quran (Al-Kaheel, 2011). Previous research has shown that listening to murattal can increase the levels of betaendorphin hormone in the early stages of pregnancy, which has a role in inhibiting the transmission of pain to the brain (Wahida et al., 2015).

The condition of relaxation when listening to the Quran is demonstrated by a description of the activity of the brain, which is dominated by the a wave (Isa et al., 2014). It was also found that the state of relaxation reached while listening to murattal helps with anxiety. Alivian et al. (2019) showed that listening to murattal can overcome the anxiety experienced by kidney failure patients who underwent hemodialysis. The calming effect has also been found to help elderly people overcome sleep disorders (insomnia) (Oktora et al., 2016).

There is still a lack of non-pharmacological therapies performed in the ICU due to the limited manpower and time of the ICU officers. Generally, image guidance, music therapy, prayer, and assisted animal therapy are performed in ICU wards (Urden et al., 2014), while research on the therapeutic effects of murattal listening in the ICU is still limited. Therefore, this study aims to identify the effect of listening to murattal on the pain experienced by ICU patients.

\section{METHOD}

\section{Study design}

This is a quasi-experimental study with a Pretest-Posttest Group Control Design (Sastroasmoro \& Ismael, 2014). The treatment group received murattal listening therapy through headphones for 15 minutes. The control group only put on headphones for 15 minutes and were not playing murattal. This research was conducted on patients in the ICU ward of Prof. Margono Soekarjo Hospital, Purwokerto, from October to December 2019.

\section{Sample}

The consecutive sampling technique was used to select a total of 40 respondents, who were then divided into the treatment and control groups, where each group consists of 20 respondents, respectively. The following are the inclusion criteria: (1) above 18 years of age; (2) consent from the patients' family; (3) Muslim. And the exclusion criteria are as follows: (1) a history of hearing loss and (2) a Glasgow Coma Scale (GCS) score of less than 9.

\section{Data collection}

The pain score was measured by the Critical Pain Observation Tool (CPOT). The CPOT has high validity and reliability for measuring pain in ICU patients, identifies consistent pain changes, and can be used in intubated patients (Varndell et al., 2017; Boitor et al., 2016; Urden et al., 2014). The tool was used for patients' that have lost consciousness. The CPOT has several indicators for measurement, such as facial expression, body movement, muscle tension and vocalization, or mechanical adaptation of the ventilator. The CPOT score ranges between 0 and 8 (Urden et al., 2014). The pain score in the intervention group was measured before and after the treatment, while the control group was measured with an interval of 15 minutes between pre- and post-wearing of the headphones.

\section{Data analysis}

The difference in pain score before and after treatment in the intervention group was analyzed by the Wilcoxon test as the data was not normally distributed, while the control group used a paired t-test because the data was normally distributed. The difference in pain reduction between the intervention group and the control group was then analyzed by the Mann Whitney test because the data were not normally distributed.

\section{Ethical consideration}

This research was approved by the Ethics Committee of Prof. Dr. Margono Soekarjo Purwokerto with the approval of the Research Ethics Committee No: 420/12260 / X/2019 dated 4 October 2019.

\section{RESULTS}

The characteristics of respondents based on age and gender both in the intervention and control groups can be seen in Table 1.

\begin{tabular}{lccc}
\multicolumn{3}{l}{ Table 1. Characteristics of Respondents } & \\
\hline Characteristics & $\begin{array}{c}\text { Intervention } \\
\text { Group }\end{array}$ & $\begin{array}{c}\text { Control } \\
\text { Group }\end{array}$ & Homogeneity \\
\hline $\begin{array}{l}\text { Age, years } \\
\text { (mean, SD) }\end{array}$ & $45,3+21,39$ & $43,5+17,8$ & 0,232 \\
\hline $\begin{array}{l}\text { Gender } \\
\text { (Number,\%) }\end{array}$ & & & \\
$\quad$ Male & $7(17,5)$ & $5(25)$ & 0,731 \\
$\quad$ Female & $13(32,5)$ & $15(75)$ & \\
\hline
\end{tabular}

Table 1 shows that the characteristics of age and gender in both groups are homogeneous. The age specific Lavene's test showed a p value of 0.232 and the exact Fisher test for gender homogeneity showed a $p$ value of 0.731 .

The difference in the pre- and post-treatment pain scores in the intervention and control groups can be seen in Table 2 and 3 .

Table 2. Differences in the pain score before and after treatment in the intervention group

\begin{tabular}{lcc}
\hline & $\begin{array}{c}\text { Median } \\
\text { (min-max) }\end{array}$ & p value \\
\hline Pain score before treatment & $4,5(4-6)$ & 0,13 \\
Pain score after treatment & $4(3-5)$ & \\
\hline
\end{tabular}

Wilcoxon test

Table 3. Differences in the pain score before and after treatment in the control group

\begin{tabular}{lcc}
\hline & Mean + SD & p value \\
\hline Pain score before treatment & $4,5+0,6$ & 0,001 \\
Pain score after 15 minutes of & $4,1+0,7$ & \\
treatment & &
\end{tabular}

treatment

Paired t-test 
The results of the Wilcoxon test in the intervention group and the paired t-test in the control group showed a significant reduction in pain scores in both groups. The difference in the reduction of control and treatment groups was identified using the Mann Whitney test. The results of the statistical tests are described in Table 4.

Table 4. Differences in the reduction of pain scores in the intervention group and the control group statistical test results

\begin{tabular}{lcc}
\hline & $\begin{array}{c}\text { Median } \\
\text { (min-max) }\end{array}$ & p value \\
\hline Decreased pain score in & 0,001 & 0,24 \\
the intervention group & $(-1,00-2,00)$ & \\
Decreased pain score in & 0,001 & \\
the intervention group & $(0,00-1,00)$ & \\
\hline Mann-Whitney test & &
\end{tabular}

Table 4 illustrates that there is no difference between the intervention group and the control group in the reduction of pain scores. Based on the results of these statistical tests, it can be concluded that there is no significant effect on the pain experienced by ICU patients from listening to murattal.

\section{DISCUSSION}

The statistical test shows that there is no effect on the pain experienced by ICU patients from listening to murattal. The result of this study differs from previous studies which found that listening to murattal can help with pain reduction among hypertensive patients (Wirakhmi et al., 2018), postoperative cancer patients (Mulyani et al., 2019), and stage I labor patients (Handayani et al., 2014). Listening to the murattal has also been found to have a relaxing effect in overcoming sleep disorders in older people (Oktora et al., 2016), anxiety in patients with renal failure who underwent hemodialysis (Alivian et al., 2019), and anxiety in pre- and postsurgical patients (Faradisi \& Aktifah, 2018; Ajorpaz N. Mirbagher, M. Aghajani, 2011).

The difference of the results between this study and the previous studies may be because of the patients investigated, as this study targeted ICU patients. The ICU is a hospital unit that deals with unstable and life-threatening conditions, therefore the treatments in the ICU ward are complex and involves many drugs and procedures (Urden et al., 2014).

Pain is influenced by many factors, including age, gender, pain perception, previous pain experiences, coping mechanisms, fatigue, and anxiety. Older people have a higher threshold for pain than younger people. This is related to decreased nerve function in the delivery of pain ( $\mathrm{Li}$ et al., 2007). Logan \& Rose (2004) also argued that women express their pain more easily than men. Additionally, poor perception of the source of pain may increase pain sensation (Prasetyo, 2010). An individual's success in dealing with previous pain may also help them to adjust to pain and reduce their pain sensation (Potter \& Perry, 2005). Moreover, previous experiences related to fatigue and coping mechanisms with pain have also had an impact on the felt sensations of pain (Potter \& Perry, 2005).

Anxiety may also increase pain if the anxiousness is related to the pain felt. However, if anxiety is not related to pain, it can be a distraction that reduces the feeling of pain (Annesi et al., 2014). Potter \& Perry (2006) mentioned other factors that influence individual perceptions of pain including culture, family and social support, and health workers.
One of the barriers found in conducting research in ICU wards is the patients' unconsciousness. This is because it has made the filtering process to remove confounding variables difficult. However, age and gender are two confusing variables that can be ignored because they are homogeneous in both groups. Meanwhile, other factors have not been studied, therefore they may also lead to bias in the results of the study (Sastroasmoro \& Ismael, 2014).

Another factor that affects pain is the use of analgesic drugs and anesthetics in postoperative patients who are admitted to the ICU. The effects of anesthetics would only wear off after 24 hours (Kwon et al., 2019). The data collected in this study did not consider the time interval between the administration of anesthesia and data collection. Thus, there was a potential for bias. This is demonstrated by the significant pain reduction in the control group. The data collection in this study also did not consider the time interval between analgesics and data collection. As to the effects of anesthesia, when a person is still under the influence of analgesic drugs, they will experience pain reduction even if they do not receive additional non-pharmacological therapy. The presence of uncontrolled external variables or confounding variables in ICU patients has contributed to the ineffectiveness of listening to murattal and pain reduction.

The inefficacy of listening to murattal towards the reduction of pain experienced by ICU patients is also due to the lack of understanding of the murattals meaning by the respondents. The respondents only listened to the murattal in Arabic without reading or listening to the translation of it in their mother language. The therapeutic effect of listening to murattal can be obtained if there is a balance between the rhythm and flow of the words of the Quran, as well as the richness of its meaning. Therefore, this lack of understanding may be the cause of the suboptimal effect of listening to murattal in reducing pain. However, this initial conclusion must be further explored in the context of future research.

Pain is considered as a vital sign, along with blood pressure, pulse rate, breathing, and temperature, and should be monitored closely. Patients should not feel pain in such a way that, once they exhibit signs of pain improvement, they will receive either analgesic or sedative therapy. This condition would stabilize the pain experienced by the patients (Urden et al., 2014). This is demonstrated by a significant reduction in pain in the control group in this study. On this basis, the use of pain indicators to measure the effectiveness of nonpharmacological interventions as complementary therapies is less accurate. The number of doses of analgesic or sedative drugs during treatment can be a more objective indicator of the determination of complementary therapies in the ICU ward.

\section{CONCLUSION AND RECOMMENDATION}

The results showed that listening to murattal did not have any effect on pain reduction among ICU patients. This result is different from previous studies which were conducted with different types of patients. Therefore, further research needs to be performed by paying attention to external variables or confounding variables. In addition, studies comparing the effects of murattal listening to translation and nontranslation on pain should be conducted. In addition, the same study needs to be conducted by replacing CPOT with an analgesic dose as the research variable. 


\section{ACKNOWLEDGMENTS}

We would like to thank to the Institute for Research and Community Service of Jenderal Sudirman University, Purwokerto, that has funded this research.

\section{REFERENCES}

Ajorpaz N. Mirbagher, M. Aghajani, M. S. (2011). The Effects Of Music And Holy Quran On Patient's Anxiety And Vital Signs Before Abdominal Surgery. Evidence Based Care Journal, 1(1), 63-76. https://doi.org/10.22 038/EBCJ.2011.3765

Al-Kaheel, A. (2011). Al Qur'an The Healing Book. Tarbawi Press.

Alderson, S. M., \& Mckechnie, S. R. (2013). Unrecognised, Undertreated, Pain In ICU: Causes, Effects, And How To Do Better. Open Journal of Nursing, 3(March), 108-113. https://doi.org/10.4236/ojn.2013.31014

Alivian, G. N., Purnawan, I., \& Setiyono, D. (2019). Efektifitas Mendengarkan Murottal Dan Doa Terhadap Penurunan Kecemasan Pada Pasien Hemodialisa Di Rsud Wates. Jurnal Keperawatan Sriwijaya, 6(2), 1317.

Annesi, S. M., Brooks-brunn, J. A., Byers, J. F., Casey, P. E., Cash, J., \& Corbin, J. (2014). Brunner \& Suddarth's Textbook of Medical-Surgical Nursing. In Monographs of the Society for Research in Child Development (Vol. 79). https://doi.org/10.1111/mono.12088

Berntzen, H., Bjørk, I. T., \& Wøien, H. (2018). 'Pain Relieved, But Still Struggling' - Critically III Patients Experiences Of Pain And Other Discomforts During Analgosedation. Journal of Clinical Nursing, 2(1), 223-234. https://doi.org/10.1111/ijlh.12426

Boitor, M., Fiola, J. L., \& Gélinas, C. (2016). Validation Of The Critical-Care Pain Observation Tool And Vital Signs In Relation To The Sensory And Affective Components Of Pain During Mediastinal Tube Removal In Postoperative Cardiac Surgery Intensive Care Unit Adults. The Journal of Cardiovascular Nursing, 31(5), 425-432. https://doi.org/10.1097/JCN.000000000000 0250

Fajar. (2016). Apa Itu Mujawwad \& Murottal? http://www.ustadzkris.com/index.php/2016/03/23/apa -itu-mujawwad-murattal/

Faradisi, F., \& Aktifah, N. (2018). Pengaruh Pemberian Terapi Murottal Terhadap Penurunan Kecemasan Post Operasi. Profesi (Profesional Islam): Media Publikasi Penelitian, 15(2), 6. https://doi.org/10.2657 6/profesi.244

Handayani, R., Fajar, S. D., Asih, D. R. T., \& Rohmah, D. N. (2014). Pengaruh Terapi Murotal Al-Quran Untuk Penurunan Nyeri Persalinan Dan Kecemasan Pad Ibu Bersalin Kala I Fase Aktif. Jurnal IImiah Kebidanan, 5(2), 1-15.

Isa, I. S., Zainuddin, B. S., Hussain, Z., \& Sulaiman, S. N. (2014). Preliminary Study On Analyzing EEG Alpha Brainwave Signal Activities Based On Visual Stimulation. Procedia Computer Science, 42(C), 8592. https://doi.org/10.1016/j.procs.2014.11.037

Klein, D. G., Dumpe, M., Katz, E., \& Bena, J. (2010). Pain Assessment In The Intensive Care Unit: Development
And Psychometric Testing Of The Nonverbal Pain Assessment Tool. Heart and Lung The Journal of Acute and Critical Care, 39(6), 521-528. https://doi.org/10.1016/j.hrtlng.2010.05.053

Kwon, Y. S., Jang, J. S., Hwang, S. M., Tark, H., Kim, J. H., Lee, J. J., \& Li, Y. (2019). Effects Of Surgery Start Time On Postoperative Cortisol, Inflammatory Cytokines, And Postoperative Hospital Day In Hip Surgery: Randomized Controlled Trial. Medicine (United States), 98(24). https://doi.org/10.1097/MD.0 000000000015820

Li, L., Liu, X., \& Herr, K. (2007). Postoperative Pain Intensity Assessment: A Comparison Of Four Scales In Chinese Adults. Pain Medicine, 8(3), 223-234. https://doi.org/10.1111/j.1526-4637.2007.00296.x

Logan, D. E., \& Rose, J. B. (2004). Gender Differences In Post-Operative Pain And Patient Controlled Analgesia Use Among Adolescent Surgical Patients. Pain, 109(3), 481-487.

Mulyani, N. S., Purnawan, I., \& Upoyo, A. S. (2019). Perbedaan Pengaruh Terapi Murottal Selama 15 Menit Dan 25 Menit Terhadap Penurunan Skala Nyeri Pada Pasien Kanker Pasca Bedah. Journal of Bionursing, 1(1), 1-13. https://doi.org/10.1017/CBO9 781107415324.004

Oktora, S. P. D., Purnawan, I., \& Achiriyati, D. (2016). Pengaruh Terapi Murottal Al Quran Terhadap Kuallitas Tidur Lansia Di Unit Rehabilitasi Sosial Dewanata Cilacap. Jurnal Keperawatan Soedirman, 11(3), 168-173. http://jks.fikes.unsoed.ac.id/index.ph $\mathrm{p} / \mathrm{jks} /$ article/view/710/397

Potter, P. A., \& Perry, A. G. (2005). Buku ajar fundamental keperawatan: Konsep, proses, dan praktik. EGC.

Potter, \& Perry. (2006). Buku Ajar Fundamental Keperawatan : Konsep, Proses, Dan Praktik. EGC.

Prasetyo, S. N. (2010). Konsep dan proses keperawatan nyeri. Graha Ilmu.

Sastroasmoro, S., \& Ismael, S. (2014). Dasar Dasar Metodologi Penelitian Klinis. Sagung Seto.

Urden, L. D., Stacy, K. M., \& Lough, M. E. (2014). Critical Care Nursing : Diagnosis anda Management (7th ed.). Mosby.

Varndell, W., Fry, M., \& Elliott, D. (2017). A Systematic Review Of Observational Pain Assessment Instruments For Use With Nonverbal Intubated Critically III Adult Patients In The Emergency Department: An Assessment Of Their Suitability And Psychometric Properties. Journal of Clinical Nursing, 26(1-2), 7-32. https://doi.org/10.1111/jocn.13594

Wahida, S., Nooryanto, M., \& Andarini, S. (2015). Terapi Murotal Al-Qur' An Surat Arrahman Meningkatkan Kadar B -Endorphin Dan Menurunkan Intensitas Nyeri Pada Ibu Bersalin Kala I Fase Aktif. Jurnal Kedokteran Brawijaya, 28(3), 213-216.

Wirakhmi, I. N., Utami, T., \& Purnawan, I. (2018). Comparison Of Listening Mozart Music With Murotal Al Quran On The Pain Of Hypertension Patients. Jurnal Keperawatan Soedirman, 13(3). 